of the foot is purple, with a longitudinal orange stripe. The orange pigment is evidently the same as that of the other species, but the purple is different from the blue and does not dissolve out in formalin.

No doubt all these pigments represent " warning coloration."

East Las Vegas, N.M., U.S.A., November Io. T. D. A. Cockerell.

The Ash Constituents of Some Lakeland Leaves.

A FURTHER series of experiments bearing on the question indicated in this journal (vol. lxiii., No. 1634, p. 396) was undertaken during the summer and autumn of this year. It was deemed advisable to extend the research over a pretty wide range of subjects, so as to be able, if possible, to catch some kind of clue towards the correct elucidation of the causes operative in the case. The capital object in view was to ascertain the exact amount of inorganic constituents (especially silica and lime) which the leaves extract from the soil at different periods of their life, so as to determine whether this particular amount has any connection with the chemical composition, \&c., of that particular soil. In all cases the entire leaf and petiole were used dried at $100^{\circ}$ and then incinerated, the same vessel and the same source of heat being used for each separate incineration.

\begin{tabular}{|c|c|c|c|c|}
\hline \multirow{2}{*}{ Leaves of } & \multirow{2}{*}{ Date. } & \multirow{2}{*}{$\begin{array}{l}\text { Percentage } \\
\text { of crude } \\
\text { ash. }\end{array}$} & \multicolumn{2}{|c|}{$\begin{array}{l}\text { Percentage of silica } \\
\left.\left(\mathrm{SiO}_{2}\right) \text { and of lime ( } \mathrm{CaO} O\right) \\
\text { in the crude ash. }\end{array}$} \\
\hline & & & $\mathrm{SiO}_{2}$ & $\mathrm{CaO}$ \\
\hline $\begin{array}{lll}\text { Beech } \quad \ldots & \ldots\end{array}$ & May 17 & $4 \cdot 8$ & & \\
\hline$" \quad \ldots \quad \ldots$ & July 30 & 5 & 17 & 27.4 \\
\hline $\begin{array}{ccc}\text { Oak } & \text { (brown) } \\
\text { Od } & \ldots & \ldots\end{array}$ & $\begin{array}{l}\text { Nov. } 3 \\
\text { Aug. I7 }\end{array}$ & $\begin{array}{l}6.8 \\
5.8\end{array}$ & $\begin{array}{l}27 \cdot 2 \\
12 \cdot 2\end{array}$ & 237 \\
\hline , (brown) & Nov. 3 & $\begin{array}{l}5.0 \\
6 \cdot 8\end{array}$ & $\begin{array}{l}12.2 \\
14.5\end{array}$ & $\begin{array}{l}29 \\
37.5\end{array}$ \\
\hline $\begin{array}{llll}\text { Hazel } & \ldots & \ldots\end{array}$ & June io & 3.3 & & \\
\hline$", \quad$ (orange) & $\begin{array}{l}\text { Aug. } 4 \\
\text { Oct. } 27\end{array}$ & $\begin{array}{l}5 \cdot 7 \\
6 \cdot 3\end{array}$ & $\begin{array}{r}6.2 \\
15\end{array}$ & $\begin{array}{l}26 \cdot 8 \\
28 \cdot 6\end{array}$ \\
\hline Alder $\ldots \ldots$ & July 29 & 49 & I.8 & $3 \mathrm{I}$ \\
\hline $\begin{array}{l}\text { (falling) } \\
\text { Linden ... ... }\end{array}$ & Nov. I & 57 & I'7 & $33^{\circ} 6$ \\
\hline $\begin{array}{l}\text { Linden ... } \\
\text { (yellow }\end{array}$ & May 30 & 55 & & \\
\hline " brown) $\}$ & Oct. I8 & $10 \cdot 8$ & $2 \cdot 5$ & $34 \cdot 8$ \\
\hline $\begin{array}{ccc}\text { Ash } & \ldots & \ldots \\
& \ldots & \ldots\end{array}$ & June I2 & 77 & & \\
\hline " & Aug. 2 & 67 & I. 5 & 377 \\
\hline Ëlder $\ldots, \ldots$ & $\begin{array}{l}\text { Uct. } 27 \\
\text { May 2I }\end{array}$ & $\begin{array}{l}9.5 \\
8.7\end{array}$ & $5 \cdot 3$ & 343 \\
\hline $\begin{array}{l}\text { ", (yellow) } \\
\text { Szots pine }\end{array}$ & Oct. 24 & $8 \cdot 5$ & $9 \cdot 5$ & $3 I \cdot 5$ \\
\hline (old leaves) & Aug. I9 & $2 \cdot 5$ & 9.4 & $15^{\circ} 9$ \\
\hline
\end{tabular}

On reviewing the foregoing table there would seem at first sight to be nothing remarkable therein ; but a little collation and comparison serve to throw a more searching light upon the subject. All these trees and shrubs have sprung from a siliceous gravelly soil charged with basic constituents, but rather poor in lime (well under I2 per cent.). Nevertheless, the leaves of ash, alder and oak have managed to secure an amount of lime which may be regarded as nearly, if not quite, their full complement of that substance. The high proportion of lime in alder leaves may be referred to the very low proportion of silica ; but this is hardly feasible in the case of the ash and oak. The ash-leaf, with a feeble proportion of silica, maintains a considerable quantity of potass and an amount of lime necessary to neutralise the organic acids which it produces in very notable degree. The oak-leaf, with far less potass in autumn, demands for the annulment of its organic acids (chiefly oxalic) a supply of lime apparently commensurate with its unique faculty for the production of starch. It will be specially observed that while, as indicated by the similar ratio of ash, the leaves of beech and oak have reached on November 3 a coequal measure of decay, that of the beech is evidently farther fallen. The leaves were selected for the experiment from beech trees flourishing right vigorously on the sandy shelving banks of the bays which indent NO. I674, vOL. 65] the upper reach of Ullswater. The result was so remarkable that the experiment was repeated with every care and precaution, but the amount of silica remained as imperturbably high as before. The tree is a decisive alien in Lakeland and its seeds never ripen here, but in a sheltered situation on a sandy bottom it presents an aspect of unquestionable health and sturdy adaptation to the circumstances.

Patterdale, Westmorland.

Note on a Point of Chemical Nomenclature.

THE use made by Mr. Goodwin and myself, in a recent com. munication to the Chemical Society, of the term alphyl is the occasion of an interesting letter from "A. T. de M.," published in NATURe (October 3I, p. 648). The history of the term alphyl and its replacement by Prof. Vorländer's term arryl, or, better, aryl, the form in which it has been generally adopted, is correctly stated. In the interest of so important a matter as uniformity in chemical nomenclature I willingly agree with "A. T. de M.," and will adopt aryl instead of alphyl for monovalent aromatic hydrocarbon radicals $\left(\mathrm{C}_{6} \mathrm{H}_{5}, \mathrm{C}_{6} \mathrm{H}_{4} \mathrm{CH}_{3}\right.$, \&c. $)$.

But Prof. Vorländer goes further than this, and his view is advocated by "A. T. de M." He proposes to alter the wellunderstood meaning of the term alkyl, to retain the term alphyl with a new meaning and to introduce the combination alpharyl. These proposals seem to me not only confusing, but unnecessary. Let us retain alkyl in its old meaning, adopt aryl for monovalent aromatic hydrocarbon radicals and use $a c y l$ for all monovalent acid radicals. The terms alkylene, arylene and acylene might be adopted for the corresponding divalent radicals without introducing a new termination. For the radical benzyl and its homologues, if it be thought desirable, ar-alkyl could be employed.

Queen's College, Galway, November 17.

\section{Does Man use his Arms in Locomotion?}

In " Monkeys ; Their Affinities and Distribution," by Dr. A. R. Wallace (reprinted in his "Studies; Scientific and Social," vol. i.), the author gives (p. 183) as one of the characters in which man differs from all the monkey tribe"the perfect freedom of the hands from all part in locomotion."

My object in writing is to point out the peculiar way in which the majority of people move their arms and hands when walking or running. One may safely say that everybody, adults and children, at one time or another exercise this movement. The natural way in which children run is to "paddle" with the arms and hands, though trained runners do not do so.

Now is it not possible that this muscular movement of the fore-limbs in opposite directions in the act of locomotion is a survival of the four-legged mode of progression of man's remote ancestors? The anthropoid apes, we know, get about by the aid of their arms and hands; while the baboons walk much in the same way as dogs do. The examples and illustrations could be enlarged upon indefinitely, and it is not for me to do so. I believe that this theory has been thought of before, but I am unable to find any trace of it in the books I have consulted. I should be very grateful if any of your readers would enlighten me on the subject.

Elm House, Hampstead.

\section{CELEBRATION OF THE JUBILEE OF M. BERT HELOT.}

THE Berthelot jubilee, celebrating the fiftieth anniversary of the publication of Marcellin Berthelot's first scientific work, was held in the Great Hall of the Sorbonne, in the University of Paris, on Sunday, November 24. The President of the Republic, M. Loubet, was in the chair, surrounded by the Ministers of the Cabinet, the Ambassadors of the various countries in the French capital, and numerous delegates from foreign and from local scientific societies.

The hall, a large amphitheatre, capable of seating more than 3000 persons, was packed with those who delighted to do honour to M. Berthelot. Behind the daïs, in the 